There also exist, near the nine-mile corner at Enugu, ten 'step-pyramids ', which stand in two rows on high ground and are of red earth, each about thirty feet high and forty feet in diameter at the base. ${ }^{\mathrm{I}}$ The people who live in the villages near them know nothing about them, and associate them with a juju to prevent theft. Excavations will show them also to be royal tombs. But these are only a few examples.

Also in the Gold Coast, Sierra Leone, and the Gambia one can expect interesting finds, although probably less spectacular. Amongst other things there are the gold ornaments, stolen from time to time from old Ashanti gzaves, which still reach the Syrian pawnbrokets, who smash them up in order to sell the gold to British banks.

Archaeological finds in West Africa will be of particular interest, for they may testify that centuries ago this part of the world was in close contact with ancient civilizations, especially with the Nubian during the first to the seventh century A.D. Many tribes now living in Nigeria, for instance, claim to be able to trace back their ancestry to peoples who, as they allege, were once settled in this region of Africa.

Apart from its value to the recording archaeologist such surveys and excavations would be of immense psychological importance, if they could establish even the tudiments of a history for the present West African generation, which is searching for such a basis upon which to build its future cultural development.

(Communicated by Mrs. Eva L. R. Meyerowitz.)

\title{
Institute of West African Arts, Industries, and Social Science.
}

On the eve of going to press, we can only record briefly that the scheme for setting up an Institute of West African Arts, Industries, and Social Science has been approved by the Colonial Office. A grant of $\mathcal{f}_{12} 27,000$ has been made by the Treasury, under the Colonial Development and Welfare Act, to cover the capital and recurring expenses of the first five years.

This event bids fair to be a milestone in the history of West Africa. Although the Institute will be limited in its scope till after the war, its beginning, as a centre for research and training in arts and crafts with a view to their economic development, is none the less a notable event. 'And when, after the war, it expands into a centre of research and training in all aspects of West African culture, its potentialities will indeed be great.

One of the chief promoters of the Institute, Mr. H. V. Meyerowitz, gave a very interesting talk at the most recent of the International Discussion Group meetings held by the International African Institute and the School of Oriental and African Studies. . The substance of his paper will be published in a forthcoming number of Africa, which will be devored specially to the subject of African arts and crafts in the light of present economic conditions. Some of the innumerable and pressing problems involved will be discussed by experts in that number.

\section{Literature and Language Publications in the Gold Coast}

ONE aspect of co-ordinated planning in the Gold Coast is shown by the appointment of a committee by the Methodist Mission with the following terms of reference: 'To write under the general editorship of the Rev. Gaddiel Acquaah, a series of graded Readers in Fante from Primer I to Reader VII, which would equip the schools for the reading of, and appreciation of, the standard set by such books as Oguaa Aban, Fante Proverbs and John Wesley.'

The first books published under the auspices of this committee are $A$ Fante Word List,

I A photograph of these appeared in Nigeria, No. I6, I938, p. 299. 